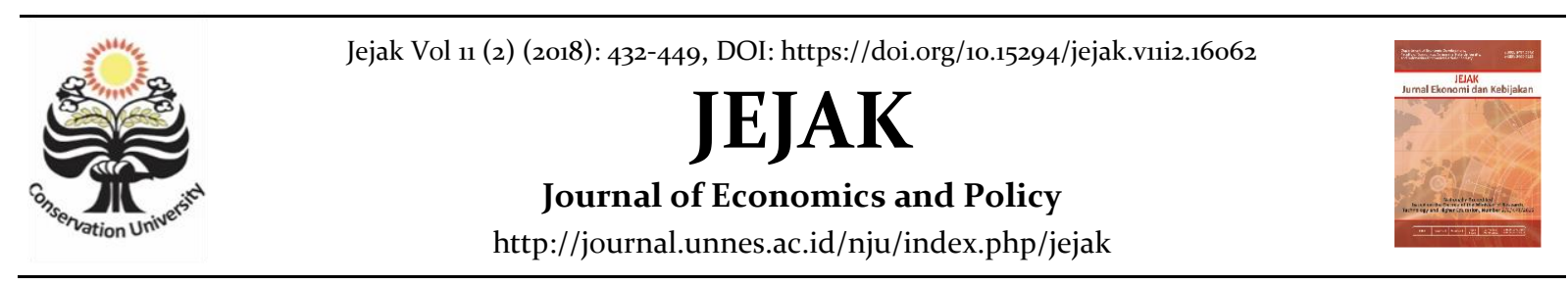

\title{
Does Political Dynasty Cause Poverty?
}

\author{
Danur Condro Guritno ${ }^{\circledR}$, Bhimo Rizky Samudro ${ }^{2}$, Albertus Magnus Soesilo³ \\ ${ }^{123}$ Magister of Economics and Development Studies, Sebelas Maret University, Surakarta \\ Permalink/DOI: https://doi.org/10.15294/jejak.v11i2.16062
}

Received: April 2018; Accepted: June 2018; Published: September 2018

\begin{abstract}
:
The delegation of central government authority to local governments can encourage policy or program targeting to be more targeted because it is indispensable for poverty reduction. Education and health are considered to be capable of alleviating poverty. This paper aims to find out the amount of budget based on Act no. 20/2003 Article 49 on National Education System (Sisdiknas) and Act no. 36/2009 Article 171 on Health in the area of political dynasty of regeneration type (vertical) and to find out the average decrease or increase of poverty rate per year in regional of political dynasty. This is descriptive research, using the ratio analysis of regional expenditure per function. This paper shows that during the period of 2005-2017, all the allocations of regional education budget of political dynasties (regeneration type) have been in accordance to the law. While the allocation of health budget, there are 3 regions from 12 regions of political dynasty that have not fulfilled the law, in addition, the area of political dynasty is able to reduce poverty with an average decrease of $0.2 \%-1.5 \%$ per year, and based on the average national poverty is 8 out of 12 regions of political dynasty in the poor category.
\end{abstract}

Keywords: political dynasty, poverty, education and health budget allocation, act on national education system, health law

How to Cite: Guritno, D., Samudro, B., \& Soesilo, A. (2018). Does Political Dynasty Cause Poverty? JEJAK: Jurnal Ekonomi dan Kebijakan, 11(2), 432-449. doi:https://doi.org/10.15294/jejak.v11i2.16062 


\section{INTRODUCTION}

Efforts to alleviate poverty by giving part of the authority to the Regional Government which generally includes fiscal, administrative and political aspects (Abimanyu and Megantara, 2009 in Nurhemi, 2015) would have the risk of full control by local elites which confine to the ruling elites of the region (Tanzi, 1995; Hofman, 2002).

The issuance of Act No. 12/2008 (amendment to Act No. 32/2004) and Act No. 9/2015 (Amendment to Act No. 23/2014) on Regional Government, stipulates that the Regional Head is no longer accountable to the legislature, but to the people, because it is directly elected by the people and the prohibition of incumbent families (Article $7 \mathrm{r}$, Act No. 8 of 2015 ) by the Constitutional Court (Decision of the Constitutional Court No. 33 / PUU-XII / 2015) stating that Article $7 \mathrm{r}$ is contradictory to Article 28J (2) of the 1945 Constitution such as adding fresh air to the practice of political dynasty.

The negative side of political dynasties, can make poverty alleviation efforts failed due to the expansion of bureaucratic problems such as patronage, cronyism, and nepotism (Putnam, 1976 in Sujarwoto, 2015). Bardhan and Mokherjee (2005) suggest three serious elite capture threats in programs designed by local governments: First, resource corruption done by local government. Second, it is called inefficiency of allocation. Finally, dynasties confine to vile institutions and harm the institution itself. In addition, Sujarwoto (2015) proves that the political dynasty is bad against poverty alleviation in Indonesia, indicated by the percentage of poverty in districts dominated by higher political dynasties than nonpolitical dynasties.
As an example of the case of Ratu Atut Dynasty in Banten Province, where there are cases of Lebak Pilkada Lebak corruption and the involvement of Ratu Atut and his family which ironically some parties think that Banten still has many poverty problems and low levels of public services. (CNN Indonesia, 9 July 2013).

However, political dynasties are not always disreputable in the public point of view. Besley and Querol (2013) assume that society will accept dynastic leadership when its economic performance is good. Mendoza et al $(2013: 2014 ; 2016)$ found that political dynasties do not affect poverty levels, but the poverty would strengthen the political dynasty. In addition, the decrease in poverty and inequality in income distribution is a direct and indirect impact of fiscal decentralization policies in which local governments play an important role through open and direct policies (Sepulveda and Vazques, 2011).

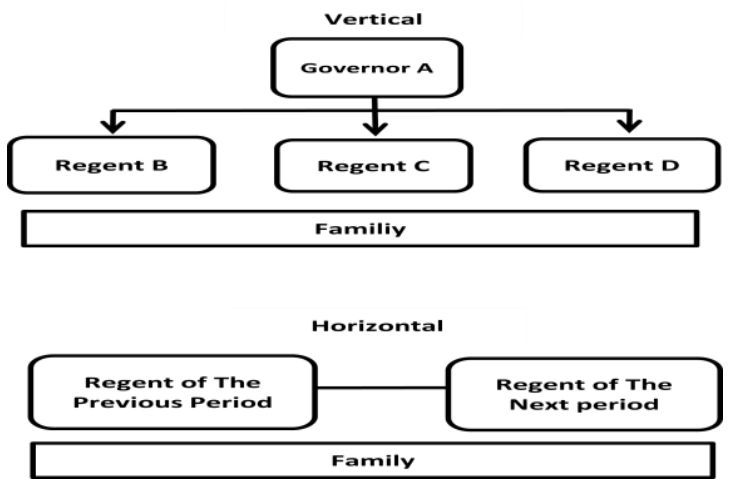

Figure 1. Type of Political Dynasties Source: Halim (2004), been analyzed

In 2013, the Ministry of Home Affairs noted that there were at least 58 regions indicated as political dynasties. Halim (2014) classifies political dynasties into two types, i.e. the Vertical Type, when the Regional Head passes through his position to one of the relatives or family by lineage and Horizontal Type, if some Regional Head in a region has a familial relation. 
One of the most interesting political characteristics of the political dynasty in Indonesia is the vertical or regenerated type where there is leadership without pause. In other words, those who inherit the same public office from their family members before them, or regional political forces committed or involving a group of people who have blood or kinship relationships (Querrubin, 2011; Asako et al., 2015; Sujarwoto, 2015). For example Kediri Regency is led by the family for 20 years, starting from two periods of Regent Sutrisno (1999-2009), continued by his wife dr. Haryanti Sutrisno until now.

Regardless of the behavior of political dynasties above, the success of a government in the era of autonomy is evident from the various performance measures that have been achieved. The form of Government's performance to the public can be seen in the amount of budget allocation which is an economic tool to improve the quality of life of the community, the level of community welfare is influenced by the decisions taken by the Government through the budget they make (Mardiasmo, 2002: 62).

Nuritomo and Rosieta (2014) found that political dynasties negatively affect the financial accountability of local governments, but have no effect on the financial performance of local governments. Another study, Kautsar (2015) found that political dynasties negatively affect local financial accountability. Areas led by political dynasties have an audit opinion worse than areas led by non-dynasties.

The delegation of central government authority to local governments can encourage policy or program targeting to be more targeted. These policies and programs are indispensable for poverty reduction in the region. Hirawan (2007); BKF \& World Bank (2011) argue that public basic services (education, health and infrastructure) are considered to be capable of alleviating poverty.

Therefore, the Central Government of Indonesia has issued Act No. 20/2003 Article 49 on National Education System (Sisdiknas) and Act No. 36/2009 Article 171 on Health which also regulates the minimum allocation to be recommended. By these regulations, Regional Governments should be able to manage and allocate the budgets appropriately (especially in the education and health sector) so that poverty alleviation can be achieved.

Sharp, et.al (1996), tries to identify the causes of poverty seen from the economic side. First, on a micro level, poverty arises because there is an inequality in the pattern of resource ownership which results in unequal income distribution. Poor people only have limited resources and low quality. Second, poverty arises due to differences in the quality of human resources. The low quality of human resources means low productivity, which in turn low wages. The low quality of human resources is due to low education, disadvantaged fate, discrimination or descent. Third, poverty arises due to differences in access to capital

In political economy, a decision-making perspective is an approach based on the maximization of the conventional welfare, autonomous and exogenous governments to the economic system so that policy-making is always oriented towards public policy (Piptone in Yustika, 2006)

Decisions in budget allocations relate to the principle of contradiction, the contradictions associated with the pattern of socioeconomic transformation as a result of 
dominant institutional change (Foster, 2005; O'Hara, 2008 in Samudro, 2012). In this case, whether the granting of authority in finances can be utilized properly, where decisionmaking will have a consequence in this case will be seen how the budget allocation in the area led by the political dynasty whether the decision taken prioritizes social interest or family interest, so the budget allocated will remain targeted and be able to improve the welfare of the community.

Referring to the principle of circular cumulative causation (CCC), Myrdal in Samudro et al (2015), if dynasties through government policy can optimally utilize the economy (in this case the budget management and economic potential of the regional autonomy era), it will improve welfare and reduce poverty, so the government must intervene through policy so that the economic activities that come do not gather or clustered in a particular area or group. In other words, the circular in poverty is cumulative because the development benefits in aggregate with it's spread effect does not necessarily occur because of institutional constraints in distributing those benefits.

The Table 1 above shows that the era of autonomy, socio-economic performance of the majority of political dynasties (regeneration type) shows that the average GDP is high, with high poverty and relatively low inequality, which means uneven distribution of income as a contribution to GDP still dominated by the rich, the contribution of the poor to GDP is still small.

Accountability instruments for the management of public funds and the implementation of programs financed with public money in order to meet the needs of the community as stakeholders, so that every public budget must take sides with the interests of the people in the effort to eradicate poverty and improve the welfare of society (Mardiasmo, 2002). Sepulveda and Vazquez (2011) argue that the decline and inequality of income distribution is the impact of fiscal policy implementation either directly or indirectly, as reflected in government policy.

Table 1. Socioeconomic Performance Indicators in Political Dynasty (Regeneration Type) 2005-2017 (Average)

\begin{tabular}{llll}
\hline \multirow{2}{*}{$\begin{array}{c}\text { Region of Political } \\
\text { Dynasty }\end{array}$} & \multicolumn{3}{c}{ Sosioeconomic Performe } \\
Indicators \\
\cline { 2 - 4 }
\end{tabular}

Note: *Data is not available, but the gini index at the provincial level reaches 0.41

Source: Central of Bureu Statistic, Data Processed

According to BKF and World Bank (2011), fiscal decentralization processes usually have an impact on improving public services (education, health and infrastructure). Although, it does not apply in all areas because there are areas that actually encounter obstacles. This can not be separated from the pattern of regional spending and political commitment of the Head of Region, which is expected to reduce poverty through efficient allocation and better service determination (Sujarwoto, 2015).

Based on the 1945 Constitution Article 31 (4) and Act No. 20/2003 Article 49 (1) 


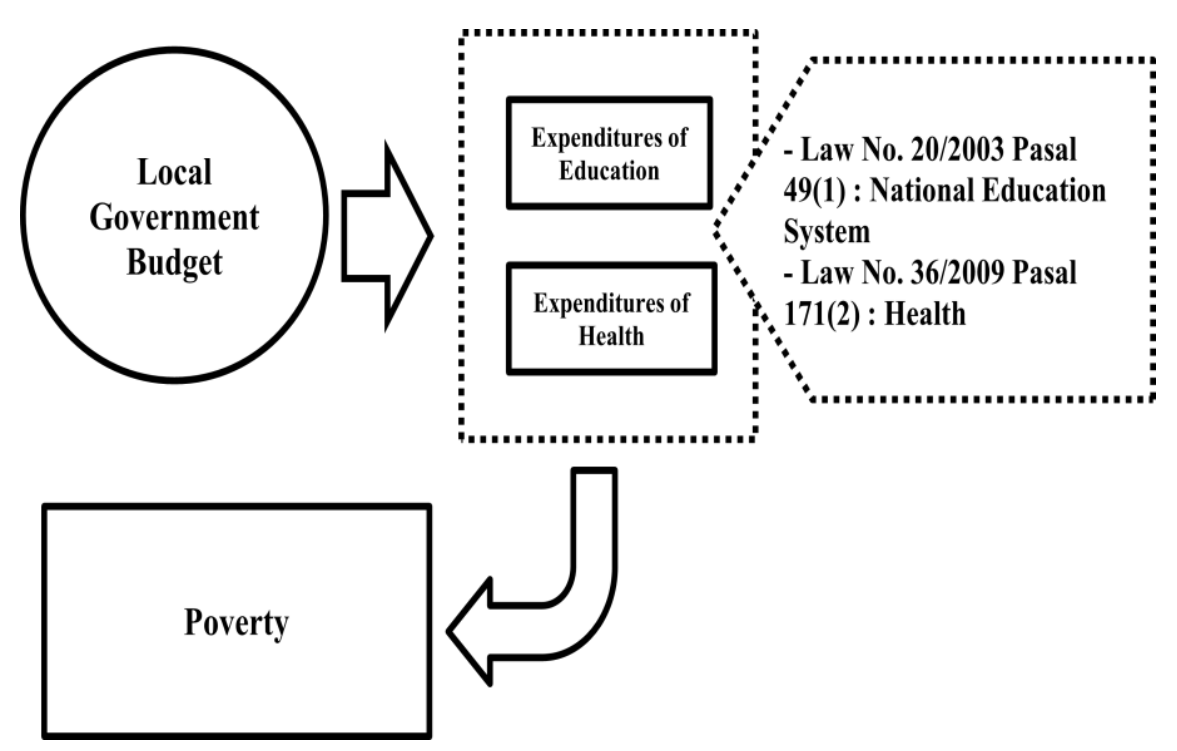

Figure 2. Education and Health Budget Allocation for Poverty Allevation Source: Mardiasmo (2002), been analyzed

clarified through the decision of the Constitutional Court. 011/PUU-III/2005 on the material test of the National Education System which states the amount of education budget allocated at least $20 \%$ of Local Government Budget (APBD) including salary for educators, while Act No. 36/2009 Article 171 (2) states that allocations in the health sector at least $10 \%$ of APBD shall be met.

This paper aims to find out the amount of budget based on Act No. 20/2003 Article 49 on National Education System (Sisdiknas) and Act No. 36/2009 Article 171 on Health in the area of political dynasty of regeneration type (vertical) and its impact on the level of poverty during the period of its leadership

\section{RESEARCH METHODS}

This research is descriptive research. Data collection technique used is purposive sampling. The data used are budgeting data per function of Local Government Budget (education and health) from regions indicated political dynasty of regeneration type (vertical) or non-pause leadership of at least two previous regent periods and one subsequent regent period (still in family relationship) in the period of $2005^{-2} 2017$ from the Ministry of Finance of RI and Poverty Index (Head-Count Index) from BPS Indonesia.

The analytical technique employed, is descriptive statistical analysis which aims to see how the implementation of laws related to the allocation of education and health in the regions indicated regeneration type (vertical) political dynasty by calculating the ratio of expenditure analysis per function to total regional expenditure.

While the poverty rate is the trend of poverty data during the period of political dynastic leadership and calculate the average poverty rate / annual decline. 


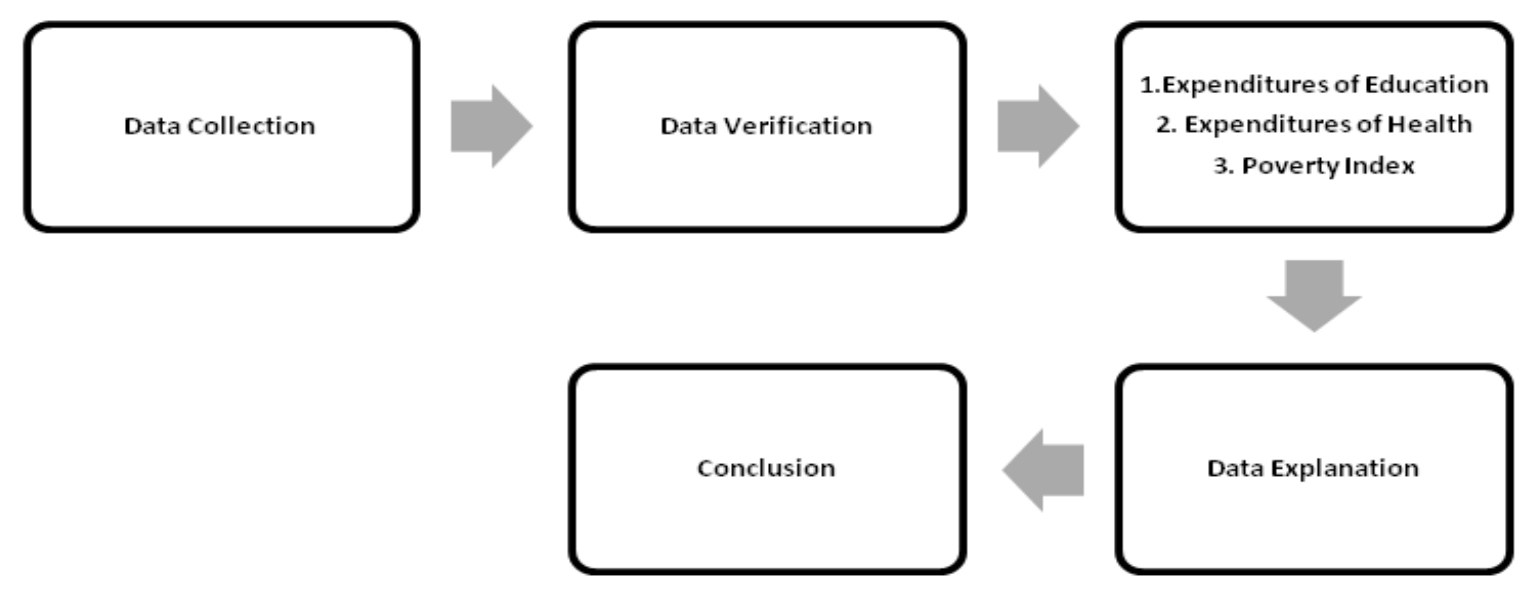

Figure 3. Descriptive Analysis Diagram

\section{RESULTS AND DISCUSSION}

If you look at the characteristics of political culture in Indonesia is very interesting, as a postcolonial state, some people have a political culture that places the position of political behavior with the form of political dynasty as a lasting power. The political dynasty shows the status quo through its family, showing that close relatives are a tool for building strong power or can be interpreted as a power embryo (Izazi in Suyadi, 2014).

Mair (1991) in Agustino (2014) said that the family is a biological group and also a social group that has a permanent membership, because it is connected through aspects of heredity, marriage, or host family, so that the main responsibility is given, namely responsibility for achieving the desired economic, social and political status, and embodying a sense of closeness with one another.

Referring to Olson's (1993) stationary bandits stating that relatives or families become political hands to exploit the economy and captivate politics, so that local rulers can build political dynasties, as in some areas by succession or regeneration, the dismissed Head of the Region may encourage his family to run for the purpose of continuing power (Table 2).

The most common practice of political dynasties is the leadership relay from husband to wife, father to child, and others, as happened in Kediri Regency. There was the first and longest dynasty in Indonesia, the Sutrisno Dynasty which had been in power since 1999-present. Starting from Ir. Sutrisno for two periods (1999-2009), followed by his wife Dr. Haryanti Sutrisno until now. Interestingly in the 2009 election, dr. Haryanti Sutrisno (legal wife) faced Nurlaila (second wife), and at the same time in 2015, incumbent Regent Dr. Haryanti Sutrisno confronts Sayekti, who is Sutrisno's third wife (Republika, 7 January 2017).

In addition, there are also political dynasties (regeneration) that are no less interesting, namely in Bangkalan Regency, where Fuad Ali Imron who has served 10 years (2003-2013) was replaced by his son, Makmun Ibnu Fuad who was then the Chair of the Regional Parliament.

Interestingly Fuad and his son also made a profitable exchange. While Makmun Ibnu replaced Fuad, his father as the Bangkalan Regent. Fuad replaced Makmun Ibnu, his son as Chairman of the Regional Parliament. So 
in August 2014, Makmun Ibnu installed his own father as the Chairperson of the Bangkalan Parliament. So that it is difficult to imagine what kind of supervision can be done by the Bangkalan Regional Parliament as legislative to the Bangkalan Regency Government because the two leaders of the institution are fathers and children.

In spite of that, the regional autonomy prevailing since 2001 has provided social space to the democratization of regional development. The mechanism of granting wide authority to regions in the financial field is expected to make local governments improve the welfare of their communities.
Decisions in budget allocations relate to the principle of contradiction, the contradictions associated with the pattern of socioeconomic transformation as a result of dominant institutional change (Foster, 2005; O'Hara, 2008 in Samudro, 2013).

In this case, whether the granting of authority in finances can be utilized properly, where decision-making will have a consequence in this case will be seen how budget allocations in the region led by the political dynasty whether the decision is taken prioritize social interest or family interest, so the budget allocated will be right on target and able to improve people's welfare.

Table 2. List of Areas Indicated by Political Dynasties Regeneration Type

\begin{tabular}{|c|c|c|c|c|c|}
\hline Province & Region & Function & Relationship* & $\begin{array}{c}\text { Start } \\
\text { Function }\end{array}$ & $\begin{array}{c}\text { Last } \\
\text { Function }\end{array}$ \\
\hline \multirow[t]{2}{*}{ South Sumatra } & Banyuasin & Regent & Father & 2003 & 2013 \\
\hline & & Regent & Son & 2013 & present \\
\hline \multirow[t]{2}{*}{ Banten } & Tangerang & Regent & Father & 2003 & 2013 \\
\hline & & Regent & Son & 2013 & present \\
\hline \multirow[t]{2}{*}{ West Java } & Cimahi & Regent & Father & 2002 & 2012 \\
\hline & & Regent & Son & 2012 & present \\
\hline \multirow[t]{2}{*}{ West Java } & Bandung Reg. & Regent & Father & 2000 & 2010 \\
\hline & & Regent & Son in law & 2010 & present \\
\hline \multirow[t]{2}{*}{ Central Java } & Klaten & Regent & Husband & 2005 & 2015 \\
\hline & & Regent & Wife & 2016 & present \\
\hline \multirow[t]{2}{*}{ Special Region of Yogyakarta } & Bantul & Regent & Husband & 1998 & 2010 \\
\hline & & Regent & Wife & 2010 & 2015 \\
\hline \multirow[t]{2}{*}{ East Java } & Probolinggo Reg. & Regent & Husband & 2003 & 2013 \\
\hline & & Regent & Wife & 2013 & present \\
\hline \multirow[t]{2}{*}{ East Java } & Kediri Reg. & Regent & Husband & 1999 & 2009 \\
\hline & & Regent & Wife & 2009 & present \\
\hline \multirow[t]{2}{*}{ East Java } & Bangkalan & Regent & Father & 2003 & 2013 \\
\hline & & Regent & Son & 2013 & present \\
\hline \multirow[t]{3}{*}{ South Sulawesi } & Takalar & Regent & Father & 2002 & 2012 \\
\hline & & Vice & & & \\
\hline & & Regent & Son & 2012 & present \\
\hline \multirow[t]{2}{*}{ Central Sulawesi } & Tolitoli & Regent & Father & 1999 & 2010 \\
\hline & & Regent & Son & 2010 & present \\
\hline \multirow[t]{2}{*}{ Moluccas } & Central Moluccas & Regent & Brother & 2002 & 2012 \\
\hline & & Regent & Brother & 2012 & present \\
\hline
\end{tabular}

Notes: ${ }^{*}$ Relationship = Family relationship between previous Regent and next Regent/Vice Regent Source: Local Government Website, The Ministry of Home Affairs of Indonesia 
Previous research has shown that poor political dynasties in dealing with poverty thereby creating poverty or undesirable performance (Bardhan, 2005, Nuritomo, 2014; Sujarwoto, 2015; Kautsar, 2015), but others assume that dynasties do not create poverty but dynasty is synonymous with poverty (Mendoza, 2013, 2014, 2016).

In addition, Besley and Querol (2013) assume that society will accept dynasties if its economic performance is good and the dynasty will collapse on its own if its economic performance is poor and Sepulveda and Vazques (2011) think that poverty occurs because it is direct and indirect policy directly and openly from the government.

Junting et al (2004) in sujarwoto (2015) explains that there are two mechanisms linking decentralization with poverty alleviation. First, the political mechanism. Political decentralization is expected to encourage community participation in local political decision-making that will create community representation so as to broaden the access of the poor to services and create power distribution that generates political stability as a cornerstone of society that will build and improve lives. Second, the economic mechanism. Decentralization is expected to reduce poverty through better efficiency and services that will improve the access of the poor to health, health, air, and others

The minimum allocation of education and health budget that has been set in the law, explicitly is at least $10 \%$, if based on Table 2, in the period 2005-2017, the majority of regions have been able to implement the law by budgeting in over $20 \%$ of the Local Government Budget (APBD), except for
Central Maluku Regency which is $15-14 \%$ in 2005 and 2006, and Tangerang Regency in 2006 which is only $18 \%$ of the Local Government Budget (APBD). On average, during 2005-2017 Klaten District showed the highest rate at an average of $57 \%$, but the whole area of political dynasty has run the mandate of Act No. 20 of 2003 Article 49 (1) well.

Meanwhile, the allocation of health budget of political dynasty region, shows that not every year in this area allocate health budget at least 10\%, from Local Government Budget (calculated in 2009), but if it is calculated in average, at least 9 areas have implemented the related law, while the other 3 regions have less than $10 \%$, i.e. Banyuasin Region (8\%), Klaten (7\%), and Central Moluccas (9\%), while Kota Cimahi is the highest with $14 \%$ allocation.

In addition Cimahi became the only area that always allocated above $10 \%$ during the period of 2005-2017. The implementation of minimum allocations regulated by law should have sufficient impact on poverty reduction. Table 3 shows the trend of poverty reduction in political dynastic regions with regeneration type (vertical), 9 regions of 12 sample regions are able to reduce poverty to below 20\%, Probolinggo, Bangkalan and Central Moluccas become areas where the poverty rate is still above $20 \%$.

However, these three areas during the period of 2005-2017 were able to reduce significantly or shorten the distance to national poverty levels. Bangkalan which showed its poverty index at $33.8 \%$ in 2005 , became $21.3 \%$ in 2017 , as well as Central Moluccas in 2005 by $37.1 \%$ became $21.2 \%$ in 2017 . 
Table 3. Implementation of Act No. 20 of 2003 article 49 on National Education System and No. 36 of 2009 article 171 on Health

Minimum Budget Allocation 20\% for Education and 10\% for Health 2005-2017 (In Percent \%)

\begin{tabular}{|c|c|c|c|c|c|c|c|c|c|c|c|c|c|c|}
\hline Regency/City & 05 & 06 & 07 & o8 & 09 & 10 & 11 & 12 & 13 & 14 & 15 & 16 & 17 & Av. \\
\hline \multicolumn{15}{|l|}{ Banyuasin } \\
\hline Education* & 26 & 28 & 27 & 20 & 37 & 37 & 39 & 32 & 38 & 45 & 38 & 30 & 35 & 34 \\
\hline Health $^{* *}$ & 5 & 7 & 6 & 7 & 9 & 8 & 7 & 7 & 8 & 10 & 11 & 13 & 11 & 8 \\
\hline $\mathrm{P}_{\mathrm{o}}$ & 20,2 & 19,7 & 17,8 & 15,4 & 13,7 & 12,4 & 11,7 & 11,3 & 12,3 & 11,9 & 12,5 & 11,7 & 11,4 & \\
\hline \multicolumn{15}{|l|}{ Tangerang Reg. } \\
\hline Education & 24 & 18 & 26 & 32 & 30 & 32 & 38 & 30 & 33 & 41 & 32 & 26 & 27 & 34 \\
\hline Health & 8 & 3 & 4 & 12 & 11 & 13 & 12 & 12 & 14 & 22 & 9 & 20 & 22 & 11 \\
\hline $\mathrm{P}_{\mathrm{o}}$ & 7,6 & 8,3 & 7,2 & 7,4 & 6,6 & 7,2 & 6,4 & 5,7 & 5,8 & 5,3 & 5,7 & 5,3 & 5,4 & \\
\hline \multicolumn{15}{|l|}{ Cimahi } \\
\hline Education & 38 & 27 & 26 & 30 & 35 & 35 & 38 & 37 & 41 & 46 & 36 & 29 & 25 & 35 \\
\hline Health & 12 & 12 & 13 & 12 & 15 & 16 & 15 & 21 & 13 & 18 & 14 & 19 & 20 & 14 \\
\hline $\mathrm{P}_{\mathrm{o}}$ & 8,4 & 7,4 & 7,3 & 8,4 & 7,1 & 7,4 & 7,2 & 6,7 & 5,6 & 5,5 & 5,8 & 5,9 & 5,8 & \\
\hline \multicolumn{15}{|l|}{ Bandung Reg. } \\
\hline Education & 47 & 39 & 41 & 45 & 44 & 45 & 57 & 50 & 45 & 50 & 46 & 53 & 38 & 46 \\
\hline Health & 7 & 6 & 8 & 9 & 11 & 12 & 10 & 11 & 11 & 16 & 14 & 14 & 17 & 10 \\
\hline $\mathrm{P}_{\mathrm{o}}$ & 13,3 & 15,2 & 13,1 & 9,4 & 8,3 & 9,3 & 9 & 8,3 & 7,9 & 7,7 & 8 & 8,1 & 8 & \\
\hline \multicolumn{15}{|l|}{ Klaten } \\
\hline Education & 59 & 47 & 51 & 51 & 59 & 58 & 64 & 62 & 57 & 68 & 54 & 44 & 36 & 57 \\
\hline Health & 3 & 5 & 6 & 7 & 7 & 7 & 6 & 6 & 5 & 11 & 10 & 11 & 10 & 7 \\
\hline $\mathrm{P}_{\mathrm{o}}$ & 22,5 & 23 & 22,3 & 21,7 & 11,5 & 17,5 & 18 & 16,7 & 15,6 & 14,6 & 14,9 & 14 & 14 & \\
\hline \multicolumn{15}{|l|}{ Bantul } \\
\hline Education & 49 & 44 & 47 & 55 & 44 & 43 & 48 & 53 & 48 & 65 & 44 & 39 & 32 & 49 \\
\hline Health & 9 & 8 & 9 & 8 & 11 & 13 & 14 & 13 & 14 & 12 & 17 & 19 & 19 & 12 \\
\hline $\mathrm{P}_{\mathrm{o}}$ & 18,2 & 20,3 & 19,4 & 18,5 & 17,6 & 16,1 & 17,3 & 17 & 16,5 & 15,9 & 16,5 & 14.6 & 14,1 & \\
\hline \multicolumn{15}{|l|}{ Probolinggo Reg } \\
\hline Education & 40 & 33 & 30 & 34 & 38 & 42 & 47 & 43 & 43 & 52 & 36 & 31 & 28 & 44 \\
\hline Health & 6 & 7 & 7 & 8 & 9 & 10 & 9 & 10 & 11 & 16 & 13 & 15 & 14 & 10 \\
\hline $\mathrm{P}_{\mathrm{o}}$ & 26,1 & 28,1 & 27,4 & 30,1 & 27,7 & 25,2 & 23,5 & 22,2 & 21,2 & 20,4 & 20,8 & 21 & 20,5 & \\
\hline \multicolumn{15}{|l|}{ Kediri Reg. } \\
\hline Education & 50 & 35 & 35 & 35 & 41 & 44 & 50 & 49 & 46 & 53 & 42 & 41 & 0,23 & 44 \\
\hline Health & 9 & 7 & 8 & 8 & 9 & 10 & 12 & 11 & 14 & 19 & 12 & 11 & 28 & 11 \\
\hline $\mathrm{P}_{\mathrm{o}}$ & 17,6 & 19,3 & 19 & 18,9 & 17,1 & 15,5 & 14,4 & 13,7 & 13,2 & 12,8 & 12,9 & 12,7 & 12,3 & \\
\hline \multicolumn{15}{|l|}{ Bangkalan } \\
\hline Education & 42 & 37 & 34 & 34 & 39 & 42 & 47 & 42 & 38 & 49 & 37 & - & 27 & 40 \\
\hline Health & 8 & 8 & 8 & 8 & 8 & 11 & 9 & 11 & 13 & 23 & 16 & - & 16 & 11 \\
\hline $\mathrm{P}_{\mathrm{o}}$ & 33,8 & 33,5 & 31,6 & 32,7 & 30,5 & 28,1 & 26,2 & 24,7 & 23,2 & 22,4 & 22,6 & 21,4 & 21,3 & \\
\hline \multicolumn{15}{|l|}{ Takalar } \\
\hline Education & 40 & 37 & 35 & 32 & 34 & 43 & 44 & 49 & 44 & 53 & 43 & 30 & 4 & 41 \\
\hline Health & 7 & 9 & 10 & 12 & 11 & 13 & 12 & 12 & 14 & 18 & 17 & 19 & 31 & 12 \\
\hline $\mathrm{P}_{\mathrm{o}}$ & 14,9 & 14,1 & 13,8 & 12,7 & 11,1 & 11,2 & 10 & 9,6 & 10,4 & 9,6 & 9,6 & 9,4 & 9,2 & \\
\hline \multicolumn{15}{|l|}{ Tolitoli } \\
\hline Education & 27 & 25 & 24 & 26 & 26 & 30 & 34 & 33 & 29 & 38 & 32 & 23 & 21 & 30 \\
\hline Health & 8 & 8 & 9 & 9 & 12 & 10 & 11 & 11 & 11 & 15 & 10 & 15 & 25 & 10 \\
\hline $\mathrm{P}_{\mathrm{o}}$ & 21,5 & 24,1 & 22,2 & 19,7 & 17,8 & 16,2 & 15 & 14,1 & 13,9 & 13,1 & 13,6 & 13,5 & 13,3 & \\
\hline \multicolumn{15}{|l|}{ Central Moluccas } \\
\hline Education & 15 & 14 & 41 & 22 & 39 & 41 & 54 & 52 & 49 & 66 & 46 & 40 & 31 & 40 \\
\hline Health & 7 & 7 & 10 & 10 & 10 & 9 & 9 & 9 & 10 & 7 & 11 & 10 & 15 & 9 \\
\hline $\mathrm{P}_{\mathrm{o}}$ & 37,1 & 38,2 & 36 & 32,6 & 30,5 & 28,4 & 25,2 & 24,1 & 22,2 & 21,4 & 22,2 & 21,7 & 21,2 & \\
\hline $\mathbf{P}_{\mathrm{o}}$ (Indonesia) & 16 & 17,8 & 16,6 & 15,4 & 14,2 & 13,3 & 12,5 & 11,7 & 11,4 & 11,3 & 11,2 & 10,7 & 10,1 & \\
\hline
\end{tabular}

Note: *Education Budget Alocation (2005-2017); **Health Budget Alocation (2005-2017), $\mathrm{P}_{\mathrm{o}}$ : Poverty Index; Av: Average; Bangkalan Regency (2016) data is not available

Source: Local Government Budget-Directorate General of Fiscal Balance, Central Bureau of Statistics (BPS), 2017, processed data 
The data presented above, which is summarized in Figure 4 shows the priority of allocations for education in the dynastic regions (regeneration type), where the budget allocations set during 2005-2017 on average far exceed the minimum allocation stipulated by the Law namely $20 \%$ of the Local Governement Budget, while the allocation for the health function is only limited to the minimum allocation amount that has been set, which is $10 \%$ of the Local Government Budget, however despite the decline in poverty, the percentage of poverty index in the dynasty area is still high or above the national poverty index (13.2\%).

More specifically, if it is generalized, the education and health budget allocations in the political dynasty during the period 20052017 show that political, education and health dynasties have been given priority, by allocating an average education budget of $41 \%$ of the Local Government Budget, and health by $11 \%$ ( Figures 4 and 5), because basic public services especially education and development spending have a very important role in poverty reduction (Hirawan, 2007; BKF 2011; Saputra dan Ni Putu, 2015).

The priority of spending in order to increase human development certainly has an impact on increasing the welfare of the community and reducing the number of poor people in terms of both quantity and quality (Widodo, 2011).

Wibowo (2003) in Widodo (2011) said that the main essence of the problem of poverty is the problem of accessibility in this case has the ability of a person or group of people in society to get their basic needs which are their rights as human beings and citizens.

There are three main factors that cause poverty, namely: (1) Low levels of health, (2) Low income, and (3) Low levels of education. Furthermore, the low level of health is a trigger for low productivity which will have an impact on the occurrence of poverty and poverty will lead to the limited reach of a person to access quality education and pay for health care costs (Mahmudi, 2007).

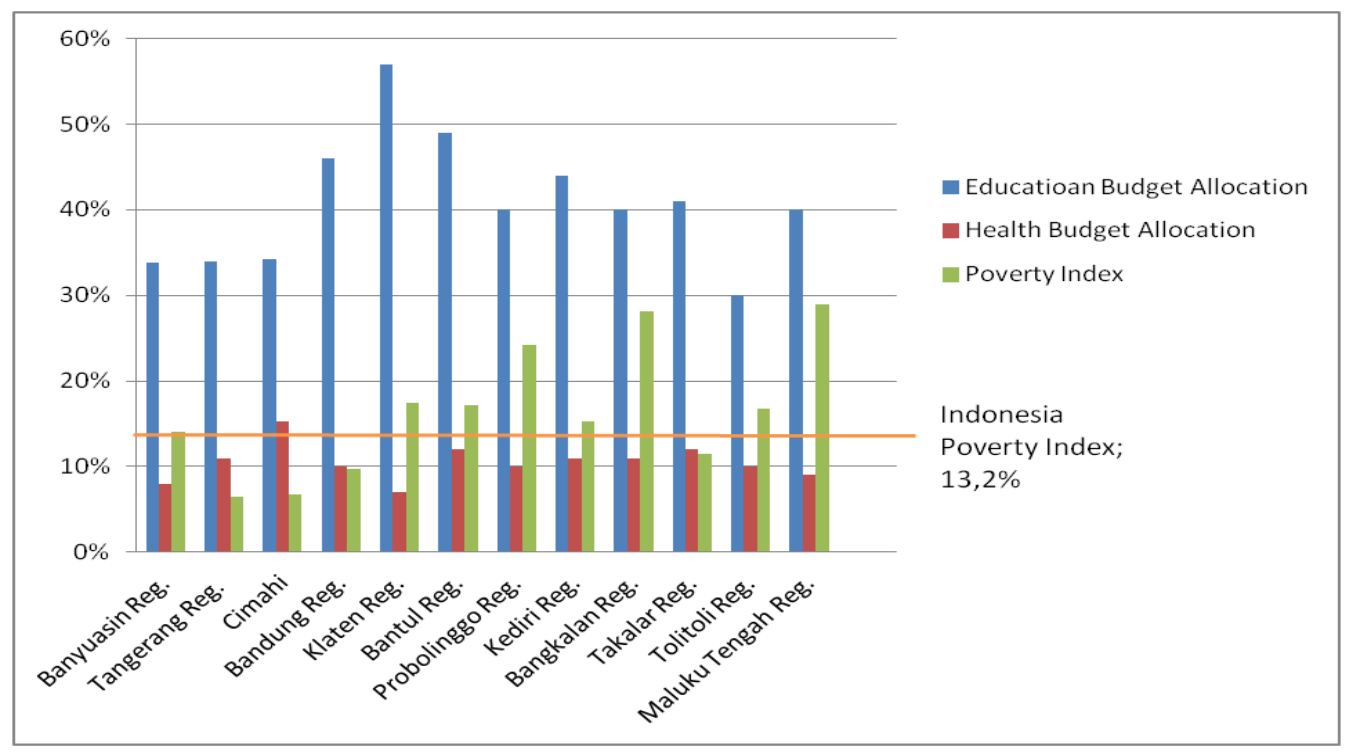

Figure 4. Average of Budget Allocation for Education and Health in the Political Dynasties Region in 2005-2017

Source: Local Goverment Bugdet, Central Bureau of Statistic, data processed 
In other words, the support of funding sources from the government (budget allocation), especially in the education and health sectors, greatly determines the quality of human development which leads to prosperity and government spending in the field of education and health both directly and indirectly which are pro-poor policies that have an impact on equity (Brata, 2005; Agusalim, 2007).

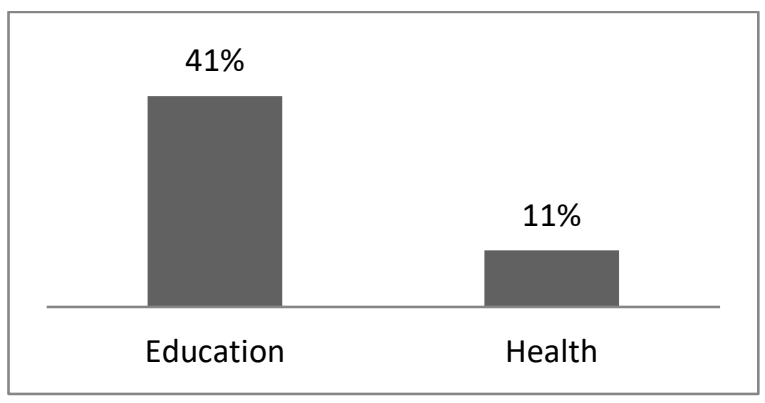

Figure 5. Education and Health Budget Allocation in Political Dynasties Area Year 2005-2017 (Average)

Source: Local Government Budget, data processed

Based on the data above, it can be seen that in general, dynastic-led regions have shown concern for improving public services through budget allocations that prioritize these according to the mandate of the law in this case is the minimum implementation of Law No. 2003 Article 49 concerning the National Education System and No. 36 of 2009 article 171 concerning Health to improve people's welfare and reduce poverty.

Fernandez (2009) argue that budgeting has three classical roles which are important debates, namely as an instrument of regulation, stabilization and redistribution (Joe Fernandes: 2009). In the context of budget regulation, it is a tool to regulate the lifestyle and behavior of the state. Here the budget has the ability to force it to influence the dynamics of socio-economic life of the community. As a stability tool, the budget provides important information about economic assumptions that are important for economic and business actors. In the context of this distribution, the budget plays its role as a tool for the welfare of society and overcoming poverty.

According to Piptone in Yustika (2006), one of the perspectives in decision making in political economy refers to an approach based on maximizing conventional welfare, the government is autonomous and exogenous to the economic system so that policy making is always oriented to public policy.

But if it is associated with public choice theory, politics is in the form of democracy which provides space for exchanges between communities, political parties, governments and bureaucrats. In this context, voters are positioned as collectors of the public (public), while the government is the provider of public policy so that in the long run they collect voter support through elections (Mitchel quoted Rachbini, 2002 in Yustika, 2006)

However, if looking at the level of poverty found in the area of political dynasty, the implementation of the minimum allocation of Law No. 20 of 2003 Article 49 concerning the National Education System and No. 36 of 2009 Article 171 on Health is more or less able to have a positive impact in order to reduce poverty even though it has not been maximized, as presented in Table 4.

Table 4 above shows the grouping of political dynasty regions regeneration-type based on the average national poverty, there are 4 regions of political dynasties of regeneration belonging to non-poor category, and 8 regions with poor category.

In addition, the implementation of education and health legislation governing 
minimum allocations for the budget (education and health) proved to be able to reduce the poverty rate, especially in political dynasty regions categorized as poor, are capable of reducing poverty above $0.5 \%$ per year except Bantul regency which can only reduce the average per year by $0.2 \%$.

Table 4. Categories of Poverty Level in Political Dynasty Region Regeneration Type

\begin{tabular}{|c|c|c|c|}
\hline Non-Poor & & Poor & \\
\hline Region & ${ }^{*} \boldsymbol{\Delta}(\mathbf{\nabla})$ & Region & ${ }^{*} \boldsymbol{\Delta}(\boldsymbol{\nabla})$ \\
\hline Tangerang & $0,20 \%$ & Banyuasin & $0,70 \%$ \\
\hline Cimahi & $0,30 \%$ & Klaten & o,8o\% \\
\hline Bandung & $0,50 \%$ & Bantul & $0,20 \%$ \\
\hline \multirow[t]{5}{*}{ Takalar } & $0,50 \%$ & Probolinggo & $0,50 \%$ \\
\hline & & Kediri & $0,50 \%$ \\
\hline & & Bangkalan & $1,10 \%$ \\
\hline & & Tolitoli & o,8o\% \\
\hline & & Central Moluccas & $1,50 \%$ \\
\hline
\end{tabular}

Based on data exposure (per capita expenditure ratio per function) and poverty trends over the period 2005-2017, it shows that political dynasties do not affect poverty, but political dynasties are identical to poverty represented by 8 out of 12 political sample regions dynasty (regeneration type) poverty rates are driven more by the direct and indirect impact of fiscal decentralization policies in which local governments play an important role through open and direct policies, as indicated by the tendency for poverty reduction, where the average poverty rate in the sample regions decreases per table year 3), this is in line with Mendoza's research $(2013,2014,2016)$, and sepuvulda (2011).

If you look at the conditions in which there is a downward trend in the level of poverty, the political dynasty has not been able to get out of the poor area, even though it has implemented Law no. 20/2003 Article 49 on National Education System (Sisdiknas) and Law no. 36/2009 Article 171 on Health, it can be indicated that in the long period of leadership there is inefficiency and ineffectiveness in channeling the budget allocation.

If referring back to the theory that has been stated, namely the principle of contradiction (Foster, 2005; O'Hara, 2008 in Samudro, 2012), the decisions in budget allocation are related to the pattern of socioeconomic transformation as a result of dominant institutional changes and the principle of cause circular cumulative consequences (Myrdal in Samudro et al, 2015), if the area of political dynasty through government policy is able to utilize the economy optimally (in this case budget management and economic potential in the era of regional autonomy), will improve welfare and reduce poverty.

Poverty that is identical with political dynasties is shown in Table 4, which shows that out of 12 political dynasties there are 8 regions in the poor category, this can also be attributed to the tendency to prioritize individual/group interests rather than the interests of society.

Allegations of corruption cases or those that have been verdicts that use regional heads in the area of political dynasties, allegedly is one of the factors that make regional linkages to political dynasties with poverty, while cases of alleged corruption in the area of political dynasties (Table 5).

Table 5 shows that almost all areas of political dynasty (type of regeneration) there are cases of alleged corruption, three of which have been verdicted (Banyuasin, Cimahi, Bangkalan) which can be concluded that there is still a tendency to prioritize individual/ group interests rather than 
community interests (the principle of contradiction) so that implementation Law no. 20/2003 Article 49 on National Education System (Sisdiknas) and Law no. 36/2009 Article 171 on Health in the context of alleviating poverty is not optimal.

Table 5. List of Corruption that Involves the Regional Head of Political Dynasties (Regeneration Type) Period 2005-2017

\begin{tabular}{ll}
\hline Corruption Case & Region \\
\hline Regent/Mayor & Banyuasin \\
Corruption & Cimahi \\
(Suspects/Verdict) & Bangkalan \\
\hline
\end{tabular}

Tangerang Reg.

Bantul

\begin{tabular}{ll} 
Alleged Corruption of & Probolinggo Reg. \\
Regent/Mayor (escaped & Kediri Reg. \\
or not examined) & Takalar \\
& Tolitoli \\
& Central Moluccas \\
\hline No Cases & Klaten* \\
& Bandung Reg. \\
\hline
\end{tabular}

Note: $\quad{ }^{*}$ Klaten; Vice Regent (wife of the previous Regent) replaces the Regent who is a suspect of corruption

Source: Various sources (newspapers and online media), have been processed

Principles of Hegemony and Contradiction attached to districts or cities whose regional heads are involved in corruption cases where family interest is more important than social interest, so that resources that should be used for regional development in order to improve community welfare and alleviate poverty, are precisely controlled by a handful of elites or certain groups

As an example of a corruption case for the regent of Bangkalan for the period 20032013 proved to be asking for a 10 percent fee for the Local Government Budget used by each Regional Work Unit (SKPD) for a decade which reached 341 billion (detik.com, September 20, 2017), based on Table 3 despite the high education and health budget allocations and able to reduce poverty levels but in the case period (20052013) the average poverty rate reached $29.4 \%$, it means that there is inefficiency and optimalization in the budget allocation due to corruption cases that occur.

Corruption case in Banyuasin, after continuing his leadership from his father, Banyuasin Regent Yan Anton Ferdian was arrested (8 years sentence) related to rice corruption cases (tied projects) and gratuities worth Rp. 1 Billion, although in his leadership several achievements have been made, including: making Banyuasin Regency a rice granary in South Sumatra Province (increasing rice production from 1.4 million tons to 2 million tons).

Likewise, the case that happened to the Cimahi Dynasty, even though the City of Cimahi was an area with a low poverty index (an average of under $10 \%$ ), but the regional head was actually involved in bribery. Regent Itoc Tochija (7-year sentence) and his successor who is also his wife, Regent Atty Suharti (4-year sentence) proved to have received bribes for the Pasar Atas Cimahi construction project worth Rp. 57 billion.

In addition, there are seven areas of political dynasty in which cases of alleged corruption are not investigated so that the widespread practice of corruption and the roots of the problem of corruption are even more difficult to solve in decentralized governments (Prud'homme, 1995 in Sujarwoto, 2015).

However, Idil Akbar in Marwiyah (2017) stated that political dynasty was not the main factor that triggered corruption, but between transactional and patron-client 
system of political culture in this country, but political dynasty vulnerable to corrupt practices, because understanding of how local resources can be more controlled by local leaders and their families.

Furthermore, the Indonesian Minister of Home Affairs, Tjahjo Kumolo said there was no problem with political dynasties, that these political dynasties do not always interpreted negatively. If there is any region related head entangled political dynasty corruption, it should not necessarily be generalized, that a political dynasty was the root of the main problems of corruption. It is supposed to be seen on a case by case basis (Marwiyah, 2017).

In line with the Indonesian Minister of Home Affairs statement, RI legislator from PDIP Dedi Gumelar said that there was nothing wrong with dynastic politics because it was permitted by law (Decision of the Constitutional Court No. 33 / PUU-XII / 2015), he confirmed that the dynasty what is formed is not a problem as long as the people are prosperous, therefore what needs to be empowered is how the welfare of its people is not its dynasty (detiknews, 17 October 2013).

However, In line with the opinion of Hirawan (2007); BKF \& World Bank (2011) that basic public services (education, health and infrastructure) are considered capable of alleviating poverty. The implementation of Law no. 20/2003 Article 49 on National Education System (Sisdiknas) and Law no. 36/2009 Article 171 on Health which requires a minimum budget allocation of $20 \%$ for education, and $10 \%$ for health, is considered quite effective in poverty alleviation efforts because the regions are required to prioritize the basic sectors that are actually needed by the community, although not all regions are capable implementing, as seen in data exposure although not yet finished from the poorer regional zones but at least closer to the national average of poverty and it is in accordance with Sepuvelda and Vazques (2011) that the decrease in poverty and inequality in income distribution is a direct and indirect impact of fiscal decentralization policies in which local governments play an important role through open and direct policies.

Referring to Mardiasmo's (2002) statement that the success of a government in the era of autonomy is evident from the various performance measures that have been achieved. The form of Government's performance to the public can be seen in the amount of budget allocation which is an economic tool to improve the quality of life of the community, the level of community welfare is influenced by the decisions taken by the Government through the budget they make.

Therefore, responsive policies are needed so that regions in espcially in political dynasty areas are able to implement effective laws effectively and efficiently. Which is illustrated in Figure 5.

(1) The issue of poverty, in order to fulfill one of the objectives of regional autonomy, namely poverty alleviation, it should fulfill the basic needs of the public through basic public services. Exposure to data that has been submitted shows an indication of the direct influence of budget allocation policies on poverty levels, in this case the budget allocation for basic public services (education, health). 


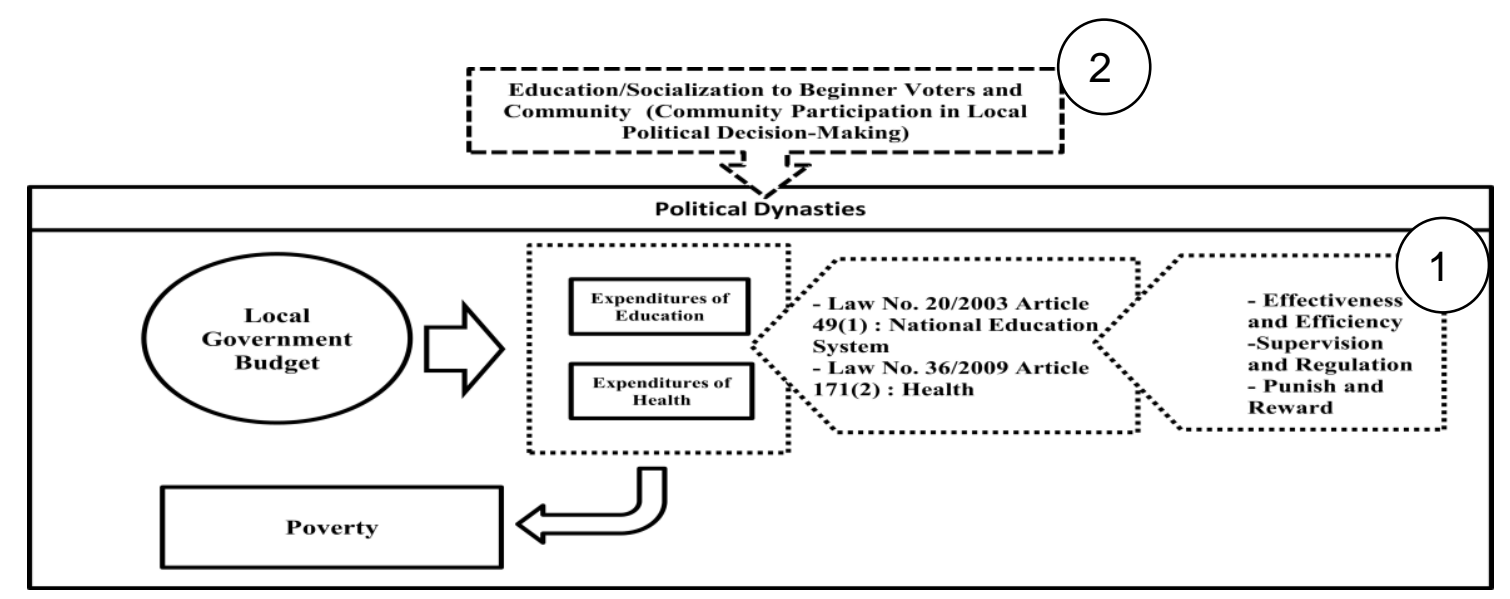

Figure 5. Responsive Policy Schemes to Implementation of Law No. 20 of 2003 Article 49 on National Education System and No. 36 of 2009 Article 171 on Health

(Minimum Budget Allocation 20\% for Education and 10\% for Health)

The mandate of the 1945 Constitution which requires the location of educational budget $(20 \%)$, health (10\%), which is described by the National Education System Act and Health Law need to be reaffirmed through a regulation that sets percentage percentage between allocation for function and personnel expenditure (operational). For example, if $\mathbf{2 0} \%$ of education includes salary then it is worth mentioning the percentage distribution "minimum" for allocation of non-personnel expenditure function and "maximum" percentage for personnel expenditure. So the essence of the required percentage nominal can be right on target (effective and efficient) and not exhausted for personnel expenditure. However, it should be supported by a central government regulation and supervision that can be punish and reward related to the implementation of the law (minimum budget allocation).

(2) Political rights mean related to political ethics which means talking about morals, because political ethics requires that all claims to the right to organize society be accounted for by basic moral principles (Suseno, 1991). Likewise the direct election election system, according to the Public
Choice Theory, places voters (voters) as collectors of the public (public) goods, while the government as a provider of public policy means that the government needs voter support through election.

Referring to Besley and Querol (2013) who assume that people will receive dynasties if their economic performance is good and dynasties will collapse by itself if the economic performance is bad, then the result of the implementation of the law can be used as a reference or measure of central government in socialization related to the political participation of the community preventing political dynasties and improving the performance of local governments, so that community can see efforts to alleviate poverty and improve welfare through priority budgets for basic public needs have been carried out or not that will create a political awareness of the community who are expected to break the chain of political dynasties.

Therfore, it is necessary to have awareness and education "aware" of politics both through the formal education curriculum or especially rural socialization through The Political Awareness Program. 
Political Awareness Program or education aware of politics from an early age (minimum age of voters) or aged 17 years (high school level) to university level should be made as a mandatory curriculum taught so that it is expected that the beginner community / voters can sort out their own prospective leaders based on their track record and quality logical. Because these ages are "swing voters" in the election and are expected to be able to stem the practice of political dynasties.

In addition, despite the need for regulations governing political dynasties, the above data also shows that there is no influence of dynastic practices on poverty, where precisely the political dynasties are able to reduce the percentage of poverty stably even though they are still unable to get out of the poor category. but at least shorten the distance to the national average poverty.

\section{CONCLUSION}

In the period of 2005-2017 almost all the leadership in the political dynasty regions has implemented the minimum limit of budget allocations for education and health budget as regulated in Act No. 20/2003 Article 49 (1) concerning National Education System and Act no. 36/2009 Article 171 (2) on Health.

During the period of 2005-2017, the political dynasty regions have implemented Act No. 20/2003 Article 49 (1) on National Education System (Sisdiknas) by education budget allocation above $20 \%$, with the highest allocation rate is Klaten Regency by average allocation per year equal to $57 \%$.

Relating to the allocation of health budget, there are 3 regions of 12 regions of regeneration-type political dynasty which have not fulfilled Law No. 36/2009 Article 171
(2) on Health, namely Banyuasin (8\%), Klaten (7\%), and Central Moluccas (9\%), while Cimahi is the highest with allocation of $14 \%$.

Athough during the period of 2005-2017, there were several allegations and cases of corruption in the political dynasty regions, however there was a trend of poverty reduction experienced by regeneration type of political dynasty regions by an average decrease of $0.2 \%-1.5 \%$ per year, and based on the average national poverty there are 4 political dynasties in the non-poor category and 8 areas in the poor category, so it can be concluded that the majority of regions having regeneration-type of political dynasties are poor areas.

The regulation of minimum allocation in the education and health budget is at least sufficient to affect the poverty reduction, so it needs to be clarified again about the percentage of minimum allocation of budget for education or health functions with the maximum budget allocation for salaries of employees which in the regulation, the budget includes salaries, education and health budgets are actually used for improving the welfare of society and poverty alleviation.

Although the scheme of political dynastic rule does not affect the level of poverty, the data show that the majority of regions under political dynasties (regeneration) are poor areas. There is a need for a policy recommendations related to the election of regional heads. Namely:

First, Socialization and education about the political dynasty to the community (especially the novice voters) in the determination of the regional head (direct regional ellection) needs to be done to break the political dynasty through the election, 
although dynasties will collapse by itself as in Bantul District, in 2015.

Second, regulation of qualification of candidates for regional head in terms of both formal and non-formal education, experience leading an organization or institution, a good track record of both achievement and criminal record.

Last, Revamping the regional head election system because the otonomy era with direct election system is an expensive political system and tend to give rise to money politics and corrupt behavior or political control by large capital owners, so So that it would be better for local elections to apply only to the local level, whereas Level II Region (Dati II) is returned to the Regional House of Representatives (DPRD) by adding a faction of community groups (community representatives) so that the monitoring of money politics is easier because the scope of supervision is less.

\section{REFERENCES}

Act No. 20 of 2003 concerning National Education System (Sisdiknas).

Act No. 12 of 2008 (Second Amendment Act No. 32 of 2004 concerning Local Goverment.

Act No. 36 of 2009 concerning Health.

Act No. 9 of 2015 (Second Amendment Act No. 23 of 2014 concerning Local Government).

Agusalim 2007, 'The Role of Government Budget Against Poverty Reduction in Indonesia', Economics and Business, Vol. 10 No. 1.

Bardhan, P \& Mokherjee, DP 2005, 'Decentralizing Anti-Poverty Program Delivery in Developing Countries', Journal of Public Economics 89:675704,

Besley, Timothy \& Querol, Marta Reynal 2013, 'Selection via Dynasties: Theory and Evidence', Manuscript in Preparation, October 24. www.econ.upf.edu

Brata, Aloysius Gunadi 2007, 'Local Public Sector Investment, Human Development and Poverty', Research institutions, Universitas Atmajaya, Yogyakarta, Februari.

Engarmen, Stanley L \& Kenneth L. Sokoloff. 2001, 'Inequality, Institutions, and Differential Paths of
Growth Among New World Economies', Workshop-Seminar. http://economics.yale.edu/

Fernandez, joe 2009, 'Poor Pro Budget: concepts and practices', $\mathrm{LP}_{3} \mathrm{ES}$, Jakarta.

Halim, Abdul 2014, 'Local Politics: Pattern, Actor and Dramatic Flow: The Powercube Theory Perspective, Capital and Stage, National Development Studies Institute, Yogyakarta.

Hirawan, Susiyati B 2007, 'Fiscal Decentralization as an Effort to Improve the Provision of Public Services (For the Poor) in Indonesia ', Speech inauguration of Professor, Faculty of Economics, University of Indonesia.

Hofman, B \& Kaiser, K 2002, 'The Making of the Big Bang and its Aftermath A Political Economy', Paper, Presented at The Conference: Can Decentralization Help Rebuild Indonesia?, University of Georgia, USA. www.worldbank.org

Kautsar, Iqbal 2015, 'Influence of Political Dynasties on Local Government Financial Accountability and Local Government Performance in Indonesia', Thesis, Universitas Gadjah Mada, Yogyakarta.

Mardiasmo 2002, Public Sector Accounting, Andi, Yogyakarta.

Mahmudi 2010, Analysis of Local Government Financial Statements, STIM YKPN, Yogyakarta.

Marwiyah, Siti, Syahrul, B, Abdul, W, 2017, 'Impact The Culture of Political Dynasties on Earthing The Constitutional Democrazy', Internatinal Journal of Civil Engineering and Technology (IJCIET), Vol. 8, Issue 12, December 2017, pp 1121-1127., ISSN Print: o976-6308, ISSN Online: 0975-6316.

Mendoza, Ronald, Edsel, B, Jr, Victor, V, \& David, Y 2013, 'Political Dynasties and Poverty: Evidence From The Phippines', 12th National Convention on Statistics, Philipines.

Mendoza, Ronald, Edsel, B, Jr, Victor, V, \& David, Y 2014, 'Political Dynasties and Poverty: Resolving the "Chicken or The Egg" Question, MPRA Paper No. 53361, posted 4. February 2014 16:06 UTC.

Mendoza, Ronald, Edsel, B, Jr, Victor, V, \& David, Y 2016, 'Political Dynasties and Poverty: Measurement and Evidence of Linkages in The Philippines', Oxford Development Studies. DOI: 10.1080/13600818.2016.1169264. ISSN: 1360-0818 (Print) 1469-9966.

Nurhemi, Guruh Suryani R 2015, 'Impact of Regional Financial Autonomy on Economic Growth in Indonesia', Bulletin of Monetary and Banking Economics, Vo. 18, No. 2, hh. 183-207, October 2015.

Nuritomo, Helda Rossieta 2014, 'Politics of Dynasty, Accountability, and Financial Performance of Local Governments in Indonesia', National Accounting Symposium XVII, Lombok.

Olson, M 1993, 'Dictatorship, Democray, and Development', The American Political Science Review, Vol. 87 No. 3 pp. $567-576$. 
Online Media 2007, 'Investigation of Alleged Corruption of Tolitoli District Head Is Terminated', Merdeka.com, Saturday December 29 2007, 19;19.

Online Media 2012, 'Zaki considers his father's corruption case to be finished', metro.sindonews.com, Monday November 26 2012, 16:53.

Online Media 2012, 'Kejari Urged to Investigate the Fat Account of Takalar Regent, pekanbaru.tribunnews.com, Thursday January 19 2012, 21;03

Online Media 2013, KPK Urged to Investigate Alleged Cases in Probolinggo', kompas.com, Sunday December 25 2013, 22;07.

Online Media 2013, 'Banten Land History Under Atut Dynasty Legs', m.cnnindonesia.com/ jul 9, 2013. www.cnnindonesia.com

Online Media 2013, 'defending Atut, Miing: Nothing Wrong with Dynasty Politics', detiknews.com, Thursday 17 October 2013, 03;27.

Online Media 2016, 'Attorney's Office Asked to Investigate Alleged Corruption of Malteng Regent, nasional.harianterbit.com, Wednesday 28 September 2016, 19:42.

Online Media, 2014, 'Dismantling Dynasty Corruption in East Java', surabayapagi.com, December 17, 2014.

Online Media, 2015, 'The Story of the Fuad Dynasty: Sacrifice a Young Wife for the Crown Prince ', cnn.indonesia.com, Thursday July 9 2015, 18;05.

Online Media, 'Escaped Corruption Case, Former Bantul Regent Pulls His Money', beritasatu.com, Saturday April 2 2016, 11;24.

Online Media, 2017, 'Proven Corruption, Banyuasin Regent Yan Anton Sentenced to Be Sentenced to 6 Years', nasional.tempo.co, Thursday March 23 2017, 18:12.

Online Media, 2017, 'Corruption Case, Former Mayor of Cimahi Atty and Husband Sentenced to 4-7 Years', news.detik.com, Wednesday 30 August 2017, 12:58.

Online Media, 2017, 'Make a shake! From the APBD alone, Fuad Amin Corruption 241 Billion, news.detik.com, Wednesday September 202017 , 15:30.

Samudro, B, R 2013, 'A political economy analysis of uneven global, regional, national and sub-national performance 1950-2010, Doctoral Dissertation, Curtin University.

Samudro, B, R, Hary, B, \& Ruhul, S 2015, 'The Uneven Regional Pattern of Ecological Capital in Indonesia: a Political Economy Perspective', Int. J. Green Economics, Vol 9 Nos 3/4.

Sujarwoto 2015, 'Decentralization, Political Dynasties and Poverty in Indonesia, JIAP, Vol. 1, No. 2, pp 16, FIA UB. ISSN 1979-7243.

Sepuvelda, Cristian, F \& Vasquez, J,M 2011, 'The Consequences of Fiscal Decentralisation on Poverty and Income Equality', Environment and Planning C: Politics and Space. ISSN: 2399-6544; Online ISSN: 2399-6552. Sage Journals.

Suseno, Franz Magnis 1991, 'Political Ethics: Basic Moral Principles of Modern State', Gramedia Pustaka Umum. Jakarta.

Tanzi, V 1995, 'Fiscal Federalism and Decentralization: A Review of Some Efficiency and Macro Economic Aspect', The World Research Obcever,pp 295-316.

Center for Study of State Expenditures on BudgetFiscal Policy Agency of the Ministry of Finance of the Republic of Indonesia \& World Bank 2011, 'Analysis of the Relationship of Balancing Funds with the Performance of Basic Public Services in Indonesia. Improving the Policy Framework for Fiscal Decentralisation (the Grand Design of Fiscal Decentralization), Analysis Report Book, Decentralization Support Facility. Jakarta.

Verdict of Constitution Court (MK) No. o11 / PUU-III / 2005 on the judicial review of Act no. 20/2003 on the National Education System.

Verdict of Constitution Court (MK) No. 33 / PUU-XIII / 2015 on the judicial review of Act no. 8/2015 on Amendment to Act no. 1/2015 on Government Regulation in Lieu of Law on the Election of Governors, Regents and Mayors (UU Election) against the 1945 Constitution.

Yustika, Ahmad Erani 2006, Institutional Economics: Definition, Theory and Strategy, Bayu Media Publising, Malang.

Widodo, Ari, Waridin, johanna Maria, K 2011, 'Analysis of the Effect of Government Expenditures on the Education and Health Sector on Poverty Alleviation Through Enhancing Human Development in Central Java Province', Journal of the Dynamics of Development Economics, Juli 2011, Vol. 1 No. 1, Hal. 25-42. 